\title{
THE BURGER COURT AND UNSPECIFIED RIGHTS: ON PROTECTING FUNDAMENTAL AND NOT-SO- FUNDAMENTAL "RIGHTS" OR "INTERESTS" THROUGH A FLEXIBLE CONCEPTION OF EQUAL PROTECTION
}

\author{
TINSLEY E. YARBROUGH*
}

In the field of substantive "rights" or "interests" not specifically addressed by the Constitution's text, the Burger Court has mounted its collective steed-with individual Justices facing opposite ends-and ridden off forcefully in several directions at once. The Court now purports to limit the fundamental rights branch of modern equal protection doctrine to those cases involving restrictions on rights "explicitly or implicitly guaranteed by the Constitution." Only in those cases and in cases involving suspect categories of classification is the strict, compelling-interest/least-restrictivealternative-means standard of scrutiny to be employed; all others require application of the more lenient rational basis equal protection formula. In practice, however, the Justices have frequently invoked rationality rhetoric-or obscured the standard of scrutiny being applied-and then subjected challenged regulations to more rigorous examination than the rational basis test would dictate.

In a related series of cases, the Court has brought out of the closet its formerly furtive relationship with substantive due process, and even buttressed that doctrine with a compelling interest formula borrowed from first amendment and equal protection cases. ${ }^{2}$ It has been reluctant, however, to enlarge upon the list of "fundamental" rights included within the "liberty" which the due process clauses guarantee. ${ }^{3}$ Finally, the Court has narrowed the reach of its selective due process attacks, made under the due process banner, on irrebuttable presumptions lacking in universal (or substantially umiversal) validity. ${ }^{4}$

* Professor of Political Science, East Carolina University. B.A. 1963, M.A. 1965, Ph.D. 1967, University of Alabama.

1. San Antonio Indep. School Dist. v. Rodriguez, 411 U.S. 1, 33-34 (1973).

2. See, e.g., Roe v. Wade, 410 U.S. $113,152-53$ (1973) (niother's right to an abortion held to be protected "liberty" guaranteed by the fourteenth antendment due process clause). (1976).

3. See, e.g., Kelley v. Johnson, 425 U.S. 238 (1976); Paul v. Davis, 424 U.S. 693

4. See Weinberger v. Salfi, 422 U.S. 749 (1975). 
The basic thesis of this Article may be briefly summarized: while the Burger Court clearly is committed to the constitutional recognition of interests not specifically mentioned in the document, its efforts toward that end have drawn it into a doctrinal quagmire. As a desirable alternative to its present approaches, it should re-bury substantive due process, dismantle the rigid, two-tiered equal protection formula which it professes to embrace but selectively ignores in practice, and adopt a flexible equal protection standard as the sole tool for affording unspecified rights or interests varying degrees of constitutional protection. This Article first surveys the recent developments alluded to above. The second section analyzes the flexible conception of equal protection now being advanced by Justice Marshall on the Court, while the third elaborates and defends the Article's thesis.

\section{THe BURger COURT AND UNSPECIFIEd Rights: RECENT DEVELOPMENTS}

\section{A. Equal Protection}

Dissenting in Shapiro v. Thompson, ${ }^{5}$ Justice Harlan developed an elaborate critique of modern equal protection doctrine. While rejecting as "unwise" the Warren Court's extension beyond race of the suspect categories branch of the "new" equal protection doctrine, ${ }^{6}$ Justice Harlan devoted primary attention to what he viewed as the "even more troublesome" fundamental rights branch: ${ }^{7}$

I think this branch of the "compelling interest" doctrine particularly unfortunate and unnecessary. It is unfortunate because it creates an exception which threatens to swallow the standard [rational basis] equal protection rule. Virtually every statute affects important rights [not necessarily given specific mention in the Constitution] ... . Rights such as these are in principle indistinguishable from those involved here, and to extend the "compelling interest" rule to all cases in which such rights are affected would go far toward making this Court a "super-legislature." This branch of the doctrine is also unnecessary. When the right affected is one assured by the Federal Constitution, any infringement can be dealt with under the Due Process Clause. But when a statute affects only matters not mentioned in the Federal Constitution and is not arbitrary or irrational, I must reiterate that I know of nothing which entitles this Court to pick out particular human activities, characterize them as "fundamental," and give them added protection under an unusually stringent equal protection test. ${ }^{8}$

5. 394 U.S. 618,655 (1969).

6. Id. at 655,659 .

7. Id. at 660 .

8. Id. at 661-62. Justice Black, Justice Harlan's principal jurisprudential antagonist on the Court, also expressed concern about the "super-legislature" implications of the "new" equal protection. See, e.g., Harper v. Virginia Bd. of Elections, 383 U.S. 663, 675-80 (1966) (Black, J., dissenting). 
Justice Stewart filed a brief concurrence challenging Justice Harlan's reading of the Shapiro Court's approach. The majority, he wrote, was not arbitrarily labeling particular activities "fundamental rights" and then subjecting their regulation to strict scrutiny. Instead, it was reserving strict scrutiny in the equal protection field for those laws having a discriminatory impact on an "established constitutional right."

Whatever the accuracy of Justice Stewart's reading of Shapiro, the Burger Court has endorsed his interpretation of the fundamental rights doctrine in the equal protection field. Its most emphatic statement to date came in San Antonio Independent School District v. Rodriguez, ${ }^{10}$ the 1973 case affirming Texas' scheme for financing public schools largely through local property taxes. Since the system at issue there resulted in budget disparities among school districts, its challengers urged application of the compelling interest standard, claiming suspect wealth discrimination and infringements on the fundamental right to an equal education. The Court, in an opinion written by Justice Powell, declined the invitation and instead found the system rationally related to a state interest in local control of education. In rejecting the claim that any law creating inequities in education is per se amenable to strict scrutiny, Justice Powell observed:

It is not the province of this Court to create substantive constitutional rights in the name of guaranteeing equal protection of the laws. Thus, the key to discovering whether education is "fundamental" is not to be found in comparisons of the relative societal significance of education as opposed to subsistence or housing. Nor is it to be found by weighing whether education is as important as the right to travel. Rather, the answer lies in assessing whether there is a right to education explicitly or implicitly guaranteed by the Constitution."11

In Justice Powell's view, failure to limit the fundamental rights branch of equal protection analysis to established constitutional rights would convert the Court, as Justice Harlan had warned, into a super-legislature. ${ }^{12}$

Even before Rodriguez, of course, the Court had rejected strict scrutiny of welfare and related regulations. In Shapiro, Justice Brennan had asserted for the majority that the one-year waiting requirement for welfare benefits at issue there denied one class of needy residents the opportunity "to obtain the very means to subsist-food, shelter, and other necessities of life." 13 Since, however, the effect of the waiting requirement on the established right of interstate travel was available as a triggering device in

9. 394 U.S. at 642.

10. 411 U.S. 1 (1973). For a recent reaffirmation of the Rodriguez approach, see Massachusetts Bd. of Retirement v. Murgia, 427 U.S. 307 (1976).

11. 411 U.S. at 33-34.

12. Id. at 31 .

13. 394 U.S. at 627. 
Shapiro, the "necessities of life" language was unnecessary for an application of strict scrutiny in the case. And the Burger Court has refused to recognize a fundamental right to the necessities of life in equal protection and due process contexts. In language foreshadowing Justice Powell's pronouncements for the Rodriguez majority, for example, Justice White concluded for the Court in a 1972 case: "We do not denigrate the importance of decent, safe, and sanitary housing. But the Constitution does not provide judicial remedies for every social and economic ill. We are unable to perceive in that document any constitutional guarantee of access to dwellings of a particular quality ...."14 During the 1975 term, moreover, the Court rejected "the proposition that a right of governmental employment per se is fundamental" in an equal protection context. ${ }^{15}$

In such cases, the Court has held, the rational basis standard traditionally employed in economic cases is applicable. ${ }^{16}$ As if to underscore the extremely lemient nature of that standard, the Court recently overruled its 1957 decision in Morey v. Doud ${ }^{17}$ - the sole Suprene Court case in alniost half a century invalidating an economic regulation on equal protection grounds. Morey had held invalid an Illinois statute exempting the American Express Company from regulations relating to the sale of money orders. In Dukes v. City of New Orleans, ${ }^{18}$ the Fifth Circuit had cited Morey as its "chief guide" in overturning an ordinance banning from the New Orleans French Quarter all pushcart vendors except those who had continually operated the same business in the Quarter for the past eight years. A unanimous Supreme Court summarily reversed, ${ }^{19}$ upholding the ordinance as rationally furthering the purpose of preserving the Quarter's appearance

14. Lindsey v. Normet, 405 U.S. 56, 74 (1972); cf. Jefferson v. Hackney, 406 U.S. 535, 546-47 (1972); Richardson v. Belcher, 404 U.S. 78, 81 (1971); Dandridge v. Williams, 397 U.S. $471,485-86$ (1970). For a critical analysis of the Court's reasoning and decisions in the welfare areas, see Reinstein, The Welfare Cases: Fundamental Rights, the Poor, and the Burden of Proof in Constitutional Litigation, 44 TEMP. L.Q. 1 (1970). For an admiring pre-Rodriguez discussion of Burger Court strictures on the scope of equal protection, see Mendelson, From Warren to Burger: The Rise and Decline of Substantive Equal Protection, 66 AM. Pol. ScI. Rev. 1226 (1972). Winter, The Changing Parameters of Substantive Equal Protection: From the Warren to the Burger Era, 23 EMORY L.J. 657 (1974), contains a useful survey of equal protection cases decided from Chief Justice Burger's appointment to the end of the 1972-73 term.

Post-Rodriguez welfare cases blurring somewhat the equal protection standard being applied include Jimenez v. Weinberger, 417 U.S. 628, 633-34 (1974), and Department of Agriculture v. Moreno, 413 U.S. 528, 533-38 (1973). See generally Coven \& Fersh, Equal Protection, Social Welfare Litigation, and the Burger Court, 51 Notre DAME LAw. 873 (1976).

15. Massachusetts Bd. of Retirement v. Murgia, 427 U.S. 307, 313 (1976).

16. The modern precedent most frequently cited is Williamson v. Lee Optical Co., 348 U.S. 483 (1955).

17. 354 U.S. 457 (1957).

18. 501 F.2d 706 (5th Cir. 1974), rev'd, 427 U.S. 297 (1976).

19. Justice Stevens did not participate in the decision. 
and customs and emphasizing that "[w] challenged solely as violating the Equal Protection Clause, this Court consistently defers to legislative determinations as to the desirability of particular statutory discriminations." 20 Characterizing Morey as "a needlessly intrusive judicial infringement on the State's legislative powers,' the Court concluded that "the decision so far departs from proper equal protection analysis in cases of exclusively economic regulation that it should be, and it is, overruled." 21

The Court's application of equal protection doctrine, of course, has not been nearly so rigid as its opinions in Rodriguez and related cases would seem to require. The Rodriguez majority narrowly limited the concept of wealth as a suspect category and the application of the compelling interest standard in wealth discrimination contexts. In dictum, it also defined suspect classes in general as those "saddled with such disabilities, or subjected to such a history of purposeful unequal treatment, or relegated to such a position of political powerlessness as to command extraordinary protection from the majoritarian political process."22 In other cases, the Court has declined to include $\operatorname{sex}^{23}$ age $^{24}$ or illegitimacy ${ }^{25}$ among the suspect

20. 427 U.S. at 303.

21. Id. at 306.

22. 411 U.S. at 28.

23. Cf. Reed v. Reed, 404 U.S. 71 (1971). But see Frontiero v. Richardson, 411 U.S. 677, 688 (1973), in which a plurality of Justices included sex within the category of suspect classifications. For illustrations of the varying treatment given sex-related classifications since Frontiero, see Califano v. Goldfarb, 97 S. Ct. 1021 (1977) (provision of Social Security Act, 42 U.S.C. $\S 402(f)(1)(D)(1970)$, requiring that a widower prove dependency upon his deceased wife in order to collect survivor's benefits held to violate equal protection where proof of dependency was not required for a widow to collect similar benefits); Stanton v. Stanton, 421 U.S. 7 (1975) (statute that distinguished on basis of sex the age at which child reached majority held violative of equal protection clause); Weinberger $v$. Wiesenfeld, 420 U.S. 636 (1975) (Social Security Act's gender-based denial of survivor benefits to widower held violative of equal protection clause); Schlesinger v. Ballard, 419 U.S. 498 (1975) (statute that required mandatory retirement of male military officers at an earlier age than female officers held rational and not violative of the equal protection clause); Geduldig v. Aiello, 417 U.S. 484, 496, n.20 (1974) (denial of disability payments to pregnant women not violative of equal protection clause); Kahn v. Shevin, 416 U.S. 351 (1974) (statute that granted property tax exemption to widow but not widower not violative of equal protection clause). In its most recent treatment of a sex-based classification in the context of a state statute, the Court struck down an Oklahoma law which allowed women to purchase 3.2 beer at eighteen years of age while forbidding men to purchase the beverage until they reached twenty-one. Justice Brennan, writing for the Court, held that the statute failed to satisfy equal protection standards for classifications by gender which require that such classifications "serve important governmental objectives and ... be substantially related to achievement of those objectives." Craig v. Boren, 97 S. Ct. 451, 457 (1976).

24. See Massachusetts Bd. of Retirement v. Murgia, 427 U.S. 307 (1976) (mandatory retirement age for state police not violative of equal protection clause).

25. See Mathews v. Lucas, 427 U.S. 495 (1976) (provisions of Social Security Act which require that only illegitimate children must prove, prior to recovery of survivor 
categories of classification. ${ }^{26}$

While the Court has generally invoked the rhetoric of traditional equal protection analysis in such cases, it recently characterized the standard to be employed in cases involving classifications based on illegitimacy as one of "less than strictest scrutiny," 27 adding that such a standard was "not a toothless one." 28 More significantly, it has actually subjected the regulations at issue in these and related cases to stricter standards of scrutiny than required by the rational basis formula. While accepting justifications for such regulations which would normally be considered inadequate under strict review standards, ${ }^{29}$ the Court has insisted that challenged provisions actually be related to asserted legislative goals and has even invalidated certain statutes clearly designed to further a legitimate governmental purpose. In Reed $v$. Reed, ${ }^{30}$ the landmark among cases of this kind, the Court declared unconstitutional a probate provision which granted men automatic preference over women in the appointment of administrators for decedents' estates. The regulation was defended as a device for reducing the workload of probate courts. Chief Justice Burger agreed for the Court that such an objective "[c]learly . . . is not without some legitimacy." $\mathrm{He}$ added, however: "To give a mandatory preference to members of either sex over members of the other, merely to accomplish the elimination of hearings on the merits, is to make the very kind of arbitrary legislative choice forbidden by the Equal Protection Clause of the Fourteenth Amendment . . . ."31 In cases involving "semi-suspect" classifications, and in certain other cases in which application of strict scrutiny was sought, the Burger Court has plowed a middle ground between the extremely stringent compelling interest stand-

benefits, that deceased wage earner was child's parent and that child was actually dependent on wage earner do not violate equal protection clause).

26. Alienage remains among the suspect classifications. See, e.g., In re Griffiths, 413 U.S. 717 (1973) (exclusion of aliens from practice of law violates equal protection clause); Graham v. Richardson, 403 U.S. 365, 372, 376 (1971) (denial of welfare benefits to aliens violative of equal protection). However, federal regulations bearing unequally on aliens are not infrequently upheld on the basis of Congress' power over immigration and naturalization. See Mathews v. Diaz, 426 U.S. 67, 79-80 (1976) (five-year residence requirement for aliens before receiving Medicare not violative of fifth amendment). But see Hampton $v$. Mow Sun Wong, 426 U.S. 88, 100-05 (1976) (exclusion of aliens from federal civil service jobs violates fifth amendment).

27. Mathews v. Lucas, 427 U.S. 495,510 (1976).

28. Id.

29. In Lucas, for example, the Court upheld a social security regulation limiting the survivor rights of illegitimate children, a provision enacted "obviously to serve administrative convenience." Id. at 509. Cf. Stanley v. Illinois, 405 U.S. 645, 656 (1972) (statute denying unwed fathers a fitness-for-custody hearing upon death of mother violative of equal protection); Shapiro v. Thompson, 394 U.S. 618, (1969) (statutes denying welfare assistance to residents of less than one year held to violate equal protection clause).

30. 404 U.S. 71 (1971).

31. Id. at 76. Also see Chief Justice Burger's opinion in Jimenez v. Weinberger, 417 U.S. 628 (1974) (distinctions based on illegitimacy under the Social Security Act). 
ard and the total lack of scrutiny implicit in the rational basis test. In a number of cases seemingly appropriate for a compelling interest mode of analysis, on the other hand, the Court has imposed somewhat imprecise but apparently less stringent standards of scrutiny. ${ }^{32}$

\section{B. Substantive Due Process}

In explaining the Warren Court's reliance on equal protection as its principal tool for expanding the scope of substantive constitutional rights, Wallace Mendelson logically assumed: "Return to nonprocedural due process was unthinkable; its unhappy history is still too vivid." ${ }^{33}$ Ironically, however, in the same term in which the Rodriguez majority purported to articulate significant restrictions on the reach of Warren Court precedents in the equal protection field, the Court also openly embraced and enhanced the concept of substantive due process. Speaking for the majority in Roe $v$. Wade, ${ }^{34}$ Justice Blackmun chose to find the ambulatory right of privacyand within it a right to abort pregnancies-not in the "penumbras" of specific Bill of Rights guarantees, ${ }^{35}$ nor in the enigmas of the ninth amendment, ${ }^{36}$ but "in the Fourteenth Amendment's concept of personal liberty." "37 Moreover, he ascribed to the doctrine a greater bite than that evident in the rhetoric of earlier cases, including perhaps those decided during the heyday of substantive due process in the economic field. Noting that only "fundamental rights" were included within the privacy concept, ${ }^{38}$ he concluded that "[w]here certain 'fundamental rights' are involved," application of the compelling interest test is required and laws touching such rights

32. See, e.g., Marston v. Lewis, 410 U.S. 679 (1973) and Burns v. Fortson, 410 U.S. 686 (voting and travel); Eisenstadt v. Baird, 405 U.S. 438 (1972) (privacy). See also Lubin v. Panish, 415 U.S. 709, 718, (1974) and Bullock v. Carter, 405 U.S. 134, 142-44 (1972) (both striking down financial barriers to candidate access to election ballots on the ground that the restrictions were not "reasonably necessary" to the accomplishment of state interests in electoral integrity).

The standard of analysis has been similarly blurred in a number of first amendment and first amendment-cum-equal protection cases. See, e.g., Pell v. Procunier, 417 U.S. 817 (1974); Storer v. Brown, 415 U.S. 724 (1974); American Party v. White, 415 U.S. 767 (1974); Branzburg v. Hayes, 408 U.S. 665 (1972). For a brief analysis of this line of cases, see Yarbrough, The Burger Court and Freedom of Expression, 33 WASH. \& LEE L. REv. 37, 81-82 (1976).

In a sympathetic discussion of early Burger Court decisions blurring the standards of equal protection, Professor Gunther has advocated means-oriented scrutiny of challenged legislation as an alternative to the "new" equal protection. See Gunther, The Supreme Court, 1971 Term-Foreword: In Search of Evolving Doctrine on a Changing Court: A Model for a Newer Equal Protection, 86 HARv. L. REv 1 (1972).

33. Mendelson, supra note 14 , at 1232.

34. 410 U.S. 113 (1973). See also Doe v. Bolton, 410 U.S. 179 (1973).

35. See Griswold v. Connecticut, 381 U.S. 479, 484 (1965).

36. Id. at 486-99 (Goldberg, J., concurring).

37. 410 U.S. at 153.

38. Id. at 152 . 
are to be narrowly drawn. ${ }^{39}$ Justice Blackmun quoted approvingly ${ }^{40}$ from Justice Holmes' dissent in Lochner v. New York ${ }^{41}$ attacking that Court's use of substantive due process to rule on the wisdom of legislation and admonishing the majority that "the accident of our finding certain opinions natural and familiar or novel and even shocking ought not to conclude our judgment upon the question whether statutes embodying them conflict with the Constitution of the Umited States." 42 As Justice Rehnquist acidly observed in dissent, however, the result reached by the Roe majority was "more closely attuned to the majority opinion of Mr. Justice Peckham in [the Lochner] case." 43

Its expansive rhetoric to the contrary, Roe has not been the harbinger of a broad and vigorous application of substantive due process by the Burger Court. In one recent case, ${ }^{44}$ in fact, the Court, speaking through $R o e$ dissenter Justice Rehnquist, appeared to read Roe as basing the right of privacy on the penumbral concept, in the manner of Justice Douglas' opinion in Griswold v. Connecticut, ${ }^{45}$ rather than on substantive due process. Citing Roe, Justice Rehnquist wrote: "While there is no 'right of privacy' found in any specific guarantee of the Constitution, the Court has recognized that 'zones of privacy' may be created by more specific constitutional guarantees and thereby impose himits upon governmental power."46 More significantly, the Court has been reluctant to expand the scope of substantive rights covered by the due process guarantee and has appeared to adopt a two-tiered (or, perhaps, multi-tiered) substantive due process formula in cases involving noneconomic activities which bears some resemblance to its articulated approach in the equal protection field.

Paul v. Davis, ${ }^{47}$ decided during the $1975-76$ term, gave the word "liberty" in the due process clauses an unusually restrictive reading. Police in the Louisville, Kentucky, area had circulated to about 800 merchants a five-page flyer containing mugshots of "active shoplifters." For fifteen years, area police had circulated similar notices for a variety of offenses, and included in the flyers were numerous individuals who had never been convicted of any crime and whose only "offense" was having been arrested for shoplifting. Among those identified in the flyer as "known to be active in [the shoplifting] field" was one Edward Charles Davis, III, whose photo

39. Id. at 155.

40. Id. at 117 .

41. 198 U.S. 45 (1905).

42. Id. at 76 .

43. 410 U.S. at 174.

44. Paul v. Davis, 424 U.S. 693 (1976).

45. 381 U.S. 479 (1965).

46. 424 U.S. at $712-13$.

47. 424 U.S. 693 (1976). 
and name appeared on the second page. Davis had been arrested by a store's security police more than seventeen months before distribution of the flyer. Prior to the flyer's circulation, his case had been put into an inactive file; shortly after its distribution, the case had been dismissed. Davis brought suit for injunctive relief and damages in federal district court, claiming that circulation of the flyer demied him due process in that the practice inhibited him from entering business establishments and seriously impaired his future employment opportumities. The district court dismissed, but the court of appeals reversed the dismissal, citing Wisconsin $v$. Constantineau.$^{48}$ The Supreme Court, speaking through Justice Rehnquist, reversed the court of appeals and upheld the challenged practice.

Constantineau had invalidated Wisconsin's "posting law," under which liquor sales to persons designated excessive drinkers were prohibited and notices to that effect were posted in retail liquor outlets. In striking down the statute, Justice Douglas concluded for the Court: "Where a person's good name, reputation, honor, or integrity is at stake because of what the government is doing to him, notice and an opportunity to be heard are essential." 49 In Paul, ${ }^{50}$ Justice Rehnquist distinguished Constantineau and related cases ${ }^{51}$ and rejected "the proposition that reputation alone, apart from some more tangible interests such as employment, is either 'liberty' or 'property' by itself sufficient to invoke the procedural protection of the Due Process Clause." 52 The earlier cases, he wrote, had involved not only injury to reputation but also governmental action altering an individual's legal status:

[T] he governmental action taken [in Constantineau] deprived the individual of a right previously held under state law-the right to purchase or obtain liquor in common with the rest of the citizenry. "Posting," therefore, significantly altered his status as a matter of state law, and it was that alternation of legal status which, combined with the injury resulting froni the defamation, justified the invocation of procedural safeguards. The "stigma" resulting from the defamatory character of the posting was doubtless an important factor in evaluating the extent of harm worked by that act, but we do not think that such defamation, standing alone, deprived Constantineau of any "liberty" protected by the procedural guarantees of the Fourteenth Amendment. ${ }^{53}$

48. 400 U.S. 433 (1971).

49. Id. at 437.

50. 424 U.S. at 701-10.

51. E.g., Goss v. Lopez, 419 U.S. 565 (1975); Board of Regents v. Roth, 408 U.S. 564 (1972); Joint Anti-Fascist Refugee Comm. v. McGrath, 341 U.S. 123 (1951); United States v. Lovett, 328 U.S. 303 (1946).

52. 424 U.S. at 701.

53. Id. at 708-09. The irony of Justice Rehnquist's reasoning is somewhat amusing. Mr. Constantineau's "legal status" was affected by the "posting law"-and he was thus granted 
Justice Rehnquist also refused to include Davis' claim within the rubric of the privacy concept. ${ }^{54}$

Justice Brennan, joined by Justice Marshall and in part by Justice White, wrote a stinging dissent. Characterizing "the enjoyment of one's good name and reputation" as "among the most cherished of rights," "55 he exclaimed:

The Court today holds that police officials, acting in their official capacities as law enforcers, may on their own initiative and without trial constitutionally condemn innocent individuals as criminals and thereby brand them with one of the most stigmatizing and debilitating labels in our society. If there are no constitutional restraints on such oppressive behavior, the safeguards constitutionally accorded an accused in a criminal trial are rendered a sham, and no individual can feel secure that he will not be arbitrarily singled out for similar ex parte punishment by those primarily charged with fair enforcement of the law. The Court accomplishes this result by excluding a person's interest in his good name and reputation from all constitutional protection, regardless of the character of or necessity for the government's actions. The result . . . is demonstrably inconsistent with our prior case law and unduly restrictive in its construction of our precious Bill of Rights . . . .56

Justice Rehnquist's opinion in Paul v. Davis placed the case closest perhaps to that line of decisions involving claims that notice and sone sort of hearing-i.e., procedural due process-are requred when liberty or property interests-usually those defined by law-are affected by government. ${ }^{57}$ The considerations underlying the Court's delineation of such interests in a procedural due process context may differ somewhat from its approach in substantive due process cases. Even so, Paul is evidence of the

relief-purely because the sale and purchase of liquor are activities traditionally subject to state control in the public interest. Since shopping and job-hunting, the activities affected by circulation of the flyer at issue in Paul, are generally free of governmental control, Davis was denied relief. The lesson of Paul, therefore, would appear to be that the Constitution provides greater protection for the "right" to purchase liquor and engage in other activities regulated by state criminal statute than for activities for which such controls are deemed unnecessary.

54. Id. at 712-13.

55. Id. at 722-23.

56. Id. at 714 .

57. See, e.g., Bishop v. Wood, 426 U.S. 341 (1976) (policeman dismissal); Mathews v. Eldridge, 424 U.S. 319 (1976) (termination of welfare benefits); Goss v. Lopez, 419 U.S. 565 (1975) (high school student suspension); Wolff v. McDonnell, 418 U.S. 539 (1974) (prison discipline); Gagnon v. Scarpelli, 411 U.S. 778 (1972) (probation revocation); Board of Regents v. Roth, 408 U.S. 564 (1972) and Perry v. Sindermann, 408 U.S. 593 (1972) (faculty dismissal); Morrissey v. Brewer, 408 U.S. 471 (1972) (parole revocation); Goldberg v. Kelly, 397 U.S. 254 (1970) (termination of welfare benefits). See also North Georgia Finishing, Inc. v. Di-Chem, Inc., 419 U.S. 601 (1975) (garnishment); Mitchell v. W.T. Grant Co., 416 U.S. 600 (1974); Fuentes v. Shevin, 407 U.S. 67 (1972) (property repossession). 
Court's reluctance to employ due process as a device for expanding the scope of constitutional rights not given specific mention in the Constitution. ${ }^{58}$ Kelley v. Johnson, ${ }^{59}$ another case decided during the 1975-76 term, suggests that even when the Court includes additional noneconomic activities within the scope of liberty in the due process guarantee, it may afford such activities only minimal constitutional protection.

After years of avoiding the issue, ${ }^{60}$ the Court in Kelley finally disposed of a constitutional challenge to a hair-grooming regulation-albeit not in the sort of student rights context in which such claims had been previously raised. The Kelley Court, in yet another opimion by Justice Rehnquist, upheld the validity of a New York county police department's regulations banning beards, flared sideburns, and hair over the collar on uniformed policemen and requiring their hair to be neat, clean, trimmed and well groomed. Justice Rehnquist was willing to "assume" that "the citizenry at large has some sort of 'liberty' interest within the Fourteenth Amendment in matters of personal appearance." $61 \mathrm{He}$ noted, however, that constitutional distinctions could be drawn between the rights of government personnel and those of the general citizenry and observed that even in the immediate past the Court had upheld significant restrictions on the first amendment activities of government employees. Moreover, he added, "If such state regulations may survive challenges based on the explicit language of the First Amendment, there is surely even more room for restrictive regulations of state employees where the claim implicates only the more general con-

58. The Court's recent rulings in cases involving claims to notice and hearing in civil proceedings also suggest development of a more restrictive stance. In Bishop v. Wood, 426 U.S. 341 (1976), the Court, in an opinion written by Justice Stevens, appeared to hold that the procedures required when an individual is deprived of a legal entitlement may be conditioned by the law creating the entitlement. See also Mathews v. Eldridge, 424 U.S. 319, 339-49 (1976) (termination of disability benefits under Social Security Act); Arnett v. Kennedy, 416 U.S. 134, 152-54 (1974) (Rehnquist, J., writing for plurality of three) (dismissal of non-probationary federal civil service employee).

In the context of criminal proceedings, of course, a number of Burger Court decisions have imposed due process standards held to be implicit in conceptions of "fundamental fairness." See, e.g., Wardius v. Oregon, 412 U.S. 470, 476 (1973) (reciprocal discovery rights in a criminal trial compelled if state required notice of alibi defense); Chambers $v$. Mississippi, 410 U.S. 284, 295, 302 (1973) (denial of right to cross-examine adverse witness and to present reliable hearsay evidence in rebuttal violative of due process). With respect to the rights of convicted persons, recent cases indicate an attitude more akin to the civil holdings cited above. See Montanye v. Haymes, 427 U.S. 236, 242 (1976) (transfer of state prisoner from one facility to another does not require hearing if incarceration is within the imposed sentence); Meachum v. Fano, 427 U.S. 215 (1976) (transfer of state prisoner to a less attractive facility does not require a hearing absent some right or justifiable expectation rooted in state law that he will not be transferred except for misbehavior).

59. 425 U.S. 238 (1976).

60. See, e.g., New Rider v. Board of Educ., 414 U.S. 1097 (1973) (Douglas, J., dissenting from denial of certiorari).

61. 425 U.S. at 244. 
tours of the substantive liberty interest protected by the Fourteenth Amendment." 62 Regulations relating to the organizational structure of police agencies enjoy a strong presumption of validity; the Court's task is merely that of determining whether the decision to enact such regulations "is so irrational that it may be branded 'arbitrary,' and therefore a deprivation of respondent's 'liberty' interest in choosing his own hairstyle." 63 The challenged regulations were valid, he concluded, because they were rationally related to the legitimate goals of encouraging police esprit de corps and making policemen more readily recognizable to the public.

Three Justices went on record as clearly recognizing a liberty interest in personal appearance under the due process guarantee, and would have given that interest stronger protection than it was accorded in the majority opinion. Justice Powell wrote a brief concurrence urging a weighing of competing interests in such cases. ${ }^{64}$ Justice Marshall, joined by Justice Brennan, registered a dissent. Excluding matters of personal appearance from the fourteenth amendment's right to liberty, Justice Marshall contended, "would be fundamentally inconsistent with the values of privacy, selfidentity, autonomy, and personal integrity that I have always assumed the Constitution was designed to protect." 65 The right was implicit, he wrote, in the right of each person to control his own person and to be left alone; its infrequent mention in earlier cases or in the nation's history meant simply that it was a right "so clear as to be beyond question. When the right has been mentioned, its existence has simply been taken for granted." 66 Justice Marshall reserved the question whether strict scrutiny should be imposed in the case because, he said, the challenged regulation "fails to pass even a minimal degree of scrutiny." $67 \mathrm{He}$ chided the majority's acceptance of the contention that the regulation would make umiformed policemen more readily identifiable to the public. Since the president of the local Patrolmen's Benevolent Association had brought the challenge to the hair rule and the International Brotherhood of Police Officers had filed an amicus brief, Justice Marshall further contended that, if anything, the rule had served to create morale problems rather than stimulate a sense of espirt de corps.

\section{Irrebuttable Presumptions}

At times, the Burger Court has subjected legislative classifications to a form of strict scrutiny through application of the doctrine that a statute

62. Id. at 245. The cases cited were Civil Serv. Comm'n v. Letter Carriers, 413 U.S. 548 (1973) and Broadrick v. Oklahoma, 413 U.S. 601 (1973).

63. 425 U.S. at 248.

64. Id. at 249.

65. Id. at 251.

66. Id.

67. Id. at 256 n.8. 
violates due process if based on an irrebuttable presumption which lacks universal, or near universal, validity. The doctrine, which has its roots in a number of early economic cases ${ }^{68}$ and in modern equal protection ${ }^{69}$ and procedural due process decisions, ${ }^{70}$ arguably was first clearly articulated and applied by the Burger Court in the 1972 case of Stanley $v$. Illinois.$^{71}$ There Justice White invoked the irrebuttable presumption formula and equal protection doctrine to strike down a statutory presumption that all unmarried fathers were unqualified to raise their children. Under the statute, unmarried fathers were denied custody of their children, without any hearing on parental fitness and without proof of neglect, even though such proceedings were required in custody cases involving married or divorced parents and unmarried mothers. Several later cases have also invoked the doctrine. Vlandis v. Kline ${ }^{72}$ invalidated a Connecticut regulation which stipulated that a student who entered a state college as an out-of-state resident would retain that status throughout his career. Cleveland Board of Education v. LaFleur $^{73}$ struck down provisions requiring mandatory leave for pregnant teachers five months and four months before an expected birth by rejecting the irrebuttable presumption that such teachers were unfit for service after the date stipulated. And in Department of Agriculture v. Murry ${ }^{74}$ the Court invalidated on the ground of overbreadth a federal food stamp regulation excluding from coverage any household containing a tax dependent of a taxpayer who was not a member of an eligible household.

Justice Stewart, who supports a somewhat restrictive interpretation of the equal protection guarantee, ${ }^{75}$ authored the Court's opinions in Vlandis and LaFleur. The doctrine of irrebuttable presumptions would appear to be a useful tool for those Justices, such as Justice Stewart, who are interested in applying strict scrutiny to certain legislative classifications without extending the reach of modern equal protection analysis. The doctrine has also had its detractors, however, and Justice Rehnquist, to no one's surprise, has

68. See Heiner v. Donnan, 285 U.S. 312 (1932); Hoeper v. Tax Comm'n, 284 U.S. 206 (1931); Schlesinger v. Wisconsin, 270 U.S. 230 (1926).

69. See Carrington v. Rash, 380 U.S. 89 (1965).

70. See Bell v. Burson, 402 U.S. 535 (1971).

71. 405 U.S. 645 (1972). While it was decided by a "Nixon era" Court, Stanley did not reflect the views of the Nixon appointees. The majority opinion, joined by Justices Brennan, Stewart and Marshall, and in part by Justice Douglas, was written by Justice White; Chief Justice Burger filed a dissent joined by Justice Blackmun, and Justices Powell and Rehnquist took no part in the decision.

72. 412 U.S. 441 (1973). The majority opinion in Vlandis, written by Justice Stewart, was concurred in by Justices Brennan, Marshall, Blackmun and Powell, with Justice White concurring in the judgment; Chief Justice Burger and Justices Douglas and Rehnquist dissented.

73. 414 U.S. 632 (1974).

74. 413 U.S. 508 (1973).

75. See Kramer v. Union Free School Dist., 395 U.S. 621, 636-37 (1969) (Stewart, J., dissenting). 
been its harshest critic on the Court. ${ }^{76}$ Justice Rehnquist, joined by the Chief Justice, filed a pointed dissent in LaFleur. A major development in the history of law, he observed, had been the establishinent of general prophylactic rules as an alternative to government by whin. The lines drawn in such regulations were rarely, if ever, perfect. Thus, said Justice Rehnquist, Justice Stewart was leading the Court "in another quixotic engagement in his apparently unending war on irrebutable presumptions," "77 which was "in the last analysis nothing less than an attack upon the very notion of lawmaking itself." 78

As if to einphasize that there are limits to the doctrine's reach, the Court rejected a number of irrebuttable presuinption claims during the same period in which Vlandis, LaFleur and Murry were decided. ${ }^{79}$ In Weinberger $v$. Salfi, ${ }^{80}$ inoreover, a majority which included Justice Stewart atteinpted to articulate the doctrine's limits. Salfi upheld a social security regulation prohibiting a wage earner's widow and stepchildren from receiving insurance benefits unless their relationships to the wage earner existed at least nine inonths prior to his death. The Court, speaking through Justice Rehnquist, einphasized once again the deference to be given social security and other welfare provisions challenged under equal protection and held that the regulation at issue was rationally related to a government interest in preventing sham narriages entered for the purpose of securing social security benefits.

76. For scholarly critiques of the doctrine, see Note, The Irrebuttable Presumption Doctrine in the Supreme Court, 87 HARv. L. REv. 1534 (1974); Note, Irrebuttable Presumptions: An Illusory Analysis, 27 STAN. L. REv. 449 (1975).

77. 414 U.S. at 657.

78. Id. at 660. Justice Powell wrote a brief concurrence with the decision in LaFleur, basing his vote on the equal protection clause and warning: "As a matter of logic, it is difficult to see the terminus of the road upon which the Court has embarked under the banner of 'irrebuttable presumptions.' "Id. at 652.

Even supporters of the doctrine have recognized that certain limits must be imposed on its reach. Dissenting in Weinberger v. Salfi, 422 U.S. 749 (1975), Justice Brennan noted that he was not contending, "nor has the Court ever held, that all statutory provisions based on assumptions about underlying facts are per se unconstitutional unless individual hearings are provided." Id. at 804 (emphasis in original).

79. Marshall v. United States, 414 U.S. 417, $422-30$ (1974) (holding that the Narcotics Rehabilitation Act of 1966 did not deny due process or equal protection by excluding addicts with two or more prior felony convictions from rehabilitative commitment as an alternative to penal incarceration); Mourning v. Family Publications Service, 411 U.S. 356, 362-63, 376-77 (1973) (rejecting irrebuttable presumption attack on regulation promulated by Federal Reserve Board pursuant to the Truth in Lending Act, which required certain disclosures by a séller who extended credit payable in more than four installments).

80. 422 U.S. 749 (1975). See also Mathews v. DeCastro, 97 S. Ct. 431, $432-36$ (1976) (holding that $\$ 202(b)(1)$ of the Social Security Act which grants benefits to a married woman under 62 whose husband retires or becomes disabled if she has a minor or dependent child in her care, but denies such benefits to a divorced woman under 62 whose ex-husband retires or becomes disabled even if she has a young or dependent child, does not violate the due process clause). 
Justice Rehnquist distinguished Stanley, Vlandis and LaFleur, on which the lower court had relied in invalidating the regulation. He noted that Stanley had involved the right to conceive and raise children, and LaFleur the freedom of choice in marriage and family life. "[A] noncontractual claim to receive funds from the public treasury," on the other hand, "enjoys no constitutionally protected status." 81 Vlandis could not be disposed of so easily since the regulation at issue there had only affected access to an education and Rodriguez had excluded education from the categories of fundamental constitutional rights. In holding Vlandis inapplicable, Justice Rehnquist observed:

Unlike the statutory scheme in Vlandis . . ., the Social Security Act does not purport to speak in terms of the bona fides of the parties to a marriage, but then make plainly relevant evidence of such bona fides inadmissable. . . . [T] The benefits here are available upon compliance with an objective criterion, one which the Legislature considered to bear a sufficiently close nexus with underlying policy objectives to be used as the test for eligibility . . . . [A]ppellees are completely free to present evidence that they meet the specified requirements. ${ }^{82}$

In short, the regulation at issue in Vlandis had been struck down because it denied students who were in fact in-state residents an opportunity to establish that status.

Echoing the language of his LaFleur dissent, Justice Rehnquist noted that extending the irrebuttable presumptions approach of Stanley, Vlandis, and LaFleur to cases of the Salfi variety "would turn the doctrine of those cases into a virtual engine of destruction for countless legislative judgments which have heretofore been thought wholly consistent with the Fifth and Fourteenth Amendments to the Constitution." 83 In Salfi and other cases for which a lenient equal protection standard was appropriate, only a rational basis was required of legislative presumptions lacking universal validity:

Under those standards, the question raised is not whether a statutory provision precisely filters out those, and only those, who are in the factual position which generated the congressional concern reflected in the statute. Such a rule would ban all prophylactic provisions . . . . Nor is the question whether the provision filters out a substantial part of the class which caused congressional concern, or whether it filters out more members of the class than nonmembers. The question is whether Congress, its concern having been reasonably aroused by the possibility of an abuse which it legitimately desired to avoid, could rationally have concluded both that a particular limitation or qualifica-

81. 422 U.S. at 772 .

82. Id.

83. Id. 
tion would protect against its occurrence, and that the expense and other difficulties of individual determinations justified the inherent imprecision of a prophylactic rule. ${ }^{84}$

In a dissent joined by Justice Marshall, Justice Brennan attacked the Court's efforts to distinguish Vlandis and also concluded that the regulation at issue was even more irrational than other welfare provisions recently set aside by the Court's decisions. ${ }^{85}$ The regulation invalidated in Vlandis, Justice Brennan asserted, did not simply 'set 'residency,' undefined, as the criteria [sic] of eligibility" 86 and then deny students the opportunity to prove their status as in-state students. Instead, "it defined residency in certain ways [and its] definitions of 'resident' were precisely parallel to the statute [in Salfi], which defines 'widow' and 'child' in part by the number of months of marriage." 87

Justice Brennan's observations are well taken. In Vlandis, students were irrebuttably presumed to retain the same residency throughout their careers in Connecticut institutions of higher learning; in Salfi, certain marriages of brief duration were irrebuttably presumed to be sham arrangements. It may be, therefore, that the Court now wishes to restrict application of a strict irrebuttable presumptions approach largely to those classifications which affect recognized constitutional rights, but does not, given the case's recent vintage, wish to overrule Vlandis outright.

\section{Justice Marshall on EQual Protection}

Of the recent doctrinal innovations by the Burger Court which affect the constitutional status of interests not given specific mention in the Constitution, the Court's restrictions on the scope of modern equal protection analysis have received the most systematic criticism, principally from Justice Marshall. Justice Marshall's differences with the majority have focused chiefly on the tendency of the two-tiered approach to ossify equal protection analysis. He first articulated a flexible alternative to that technique in Dandridge $v$. Williams, ${ }^{88}$ the 1970 case in which a majority, speaking through Justice Stewart, upheld a state-imposed family ceiling of roughly $\$ 250$ per month on funds provided under the Aid to Families with Dependent Children (AFDC) program. Justice Stewart recognized that "[t]he administration of public welfare assistance . . . involves the most basic economic needs of impoverished human beings," 89 but he rejected the

84. Id. at 777 .

85. Id. at 802-03. Justice Brennan cited Murry and Jimenez v. Weinberger, 417 U.S. 628 (1974) (statutory bar to disability benefits imposed upon illegitimate children of disabled insured born after onset of disability).

86. 422 U.S. at 803.

87. Id. (emphasis in original).

88. 397 U.S. 471 (1970).

89. Id . at 485 . 
claim that there is a right to welfare benefits which would trigger strict scrutiny of the AFDC ceiling and held that the regulation was rationally related to the legitimate state objectives of encouraging employment and maintaining an equitable balance between the incomes of welfare families and those of the working poor.

Justice Marshall, joined by Justice Brennan, agreed with the contention of Justice Douglas in a separate dissent that the ceiling conflicted with applicable federal regulations. ${ }^{90}$ But his disagreement with the majority was much more broadly based. Justice Marshall saw "some resemblance"91 between the classification at issue in the case and the classification based on illegitimacy which the Court had subjected to strict scrutiny and invalidated in Levy v. Louisiana. ${ }^{92} \mathrm{He}$ also expressed doubt whether "a person whose very survival is at stake would be comforted by the knowledge that his "fundamental' rights are preserved intact" ";3 asserted that less drastic means were available for accomplishing the objectives ostensibly underlying the ceiling; indicated his skepticism that the asserted objectives were the actual purposes which the regulation was designed to serve; and concluded that, in any event, the regulation was both grossly overinclusive and underinclusive.

More significantly for purposes of this analysis, Justice Marshall contended that "[t]his case simply defies easy characterization in terms of one or the other of" the tests available under the two-tiered formula ${ }^{94}$ and asserted more broadly that "equal protection analysis of [the Dandridge] case is not appreciably advanced by the a priori definition of a 'right,' fundamental or otherwise." 95 Instead, he maintained, "concentration must be placed upon the character of the classification in question, the relative importance to individuals in the class discriminated against of the governmental benefits that they do not receive, and the asserted state interests in support of the classification.",96

Justice Marshall modeled his approach on the language of Justice Black's opinion for the Court in Williams $v$. Rhodes,${ }^{97}$ the Wallace elector case invalidating Ohio regulations which restricted party access to the ballot. Justice Black had observed that the challenged regulations affected

90. Id. at 490-508 (Marshall, J., dissenting).

91. Id. at 523 .

92. 391 U.S. 68 (1968). In Levy, the Court struck down a state court interpretation of the Louisiana wrongful death statute which denied a right of recovery to the illegitimate child of a deceased mother. The Court found "invidious discrimination" violative of the fourteenth amendment, concluding that "[l]egitimacy or illegitimacy of birth has no relation to the nature of the wrong allegedly inflicted on the mother." Id. at 72.

93. 397 U.S. at 520 n.14.

94. Id. at 520 .

95. Id.

96. Id. at $520-21$.

97. 393 U.S. 23 (1968). 
the "precious freedoms" 98 of association and suffrage and concluded that " $[t]$ he State has here failed to show any 'compelling interest' which justifies imposing such heavy burdens on the right to vote and to associate." ${ }^{99} \mathrm{He}$ prefaced his application of the compelling interest test, however, with a more general statement of the Court's task in equal protection cases, observing: "In determining whether or not a state law violates the Equal Protection Clause, we must consider the facts and circumstances behind the law, the interests which the State claims to be protecting, and the interests of those who are disadvantaged by the classification." 100 This flexible, balancing-ofinterests approach is the mode of analysis which Justice Marshall believes the Court should follow in equal protection litigation.

Dissenting in Rodriguez, Justice Marshall advanced a variation of the flexible approach which he had articulated in his Dandridge dissent. ${ }^{101} \mathrm{He}$ challenged the Rodriguez majority's conclusion that strict scrutiny should be invoked only when a challenged classification is based on a suspect criterion or infringes upon rights expressed or implied in the Constitution. The Court's conception of the fundamental rights branch of the "new" equal protection made that aspect of the compelling interest doctrine meaningless, he maintained, since recognized constitutional rights already enjoy protection under the provisions of the Constitution in which they are grounded. As an alternative, Justice Marshall advocated adoption of a sliding-scale approach: in certain cases, the degree of scrutiny given regulation of an activity or interest would depend on the significance of the activity or interest to the enjoyment of recognized constitutional rights. Since education, the interest at issue in Rodriguez, was very closely related to the enjoyment of first amendment and voting rights, said Marshall, an educational financing scheme that denies equal educational opportunities should be given "far more than the lenient scrutiny ... which the majority pursues." "102

Justice Marshall's most recent statement was occasioned by the Court's decision in Massachusetts Board of Retirement v. Murgia ${ }^{103}$ The Murgia Court summarily affirmed a statute making fifty the mandatory retirement age for members of the uniformed branch of the state police. Rejecting the claim that age is a suspect basis of classification or public employment a fundamental constitutional right, the Court upheld the regulation as rationally related to the legitimate state interest in protecting the public by assuring the physical fitness of its police.

98. Id. at 30 .

99. Id. at 31 .

100. Id. at 30 (footnote omitted).

101. San Antonio Indep. School Dist. v. Rodriguez, 411 U.S. 1, 98-110 (Marshall,. J., dissenting).

102. Id. at 110 .

103. 427 U.S. 307 (1976). 
Justice Marshall was the lone dissenter. ${ }^{104}$ As in earlier opinions, ${ }^{105}$ he contended that the majority was not actually following the rigid, two-tiered formula in many cases. "The model's two fixed modes of analysis, strict scrutiny and mere rationality," he wrote, "simply do not describe the inquiry the Court has undertaken-or should undertake-in equal protection cases. Rather, the inquiry has been much more sophisticated and the Court should admit as much." 106 In Justice Marshall's view, the rigidity of the articulated approach was its major weakness. Since legislation subjected to strict scrutiny rarely, if ever, survived challenge, the Court was naturally "hesitant to expand the number of categories of rights and classes subject to strict scrutiny, when each expansion involves the invalidation of virtually every classification bearing upon a newly covered category." 107 Yet application of the rationality test meant virtually no scrutiny at all of challenged regulations. Thus, no meaningful protection was extended under the twotiered formula to 'rights, not now classified as 'fundamental,' that remain vital to the flourishing of a free society, and classes, not now classified as 'suspect,' that are unfairly burdened by invidious discrimination unrelated to the individual worth of their members." 108 Justice Marshall praised the Court's willingness in practice to apply more flexible standards, but added:

[T] here are problems with deciding cases based on factors not encompassed by the applicable standards. First, the approach is rudderless, affording no notice to interested parties of the standards governing particular cases and giving no firm guidance to judges who, as a consequence, must assess the constitutionality of legislation before them on an ad hoc basis. Second, and not unrelatedly, the approach is unpredictable and requires holding this Court to standards it has never publicly adopted. Thus the approach presents the danger that . . . relevant factors will be misapplied or ignored. All interests not "fundamental" and all classes not "suspect" are not the same; and it is time for the Court to drop the pretense that, for purposes of the Equal Protection Clause, they are. ${ }^{109}$

Justice Marshall's support for a more flexible equal protection standard than that presently articulated by the Court does not mean, of course, that he

104. Id. at 317. Justice Stevens did not participate in the Court's decision of the case.

105. See, e.g. , Marshall v. United States, 414 U.S. 417 (1974). In Marshall the majority held that a federal law excluding drug addicts with two or more prior felony convictions from a program of rehabilitation did not constitute a denial of due process or equal protection. Justice Marshall dissented, finding it "hard to understand why a statute which . . . deprives [a man] of the opportunity even to be considered for treatment for his disease. . . should be tested under the same minimal standards of rationality that we apply to statutes regulating . . . who can own pharmacies." Id. at $432-33$.

106. 427 U.S. at 318.

107. Id. at 319 (footnote omitted).

108. Id. at 320 .

109. Id. at 321 . 
would discard entirely the compelling interest test in equal protection contexts. In Murgia, for example, he observed:

Some classifications are so invidious that they should be struck down automatically absent the most compelling state interest, and by suggesting the limitations of strict scrutiny analysis I do not mean to imply otherwise. The analysis should be accomplished, however, not by stratified notions of "suspect" classes and "fundamental" rights, but by individualized assessments of the particular classes and rights involved in each case. Of course, the traditional suspect classes and fundamental rights would still rank at the top of the list of protected categories, so that in cases involving those categories analysis would be functionally equivalent to strict scrutiny. Thus, the advantages of the approach I favor do not appear in such cases, but rather emerge in those dealing with traditionally less protected classes and rights. ${ }^{110}$

\section{Flexible Equal Protection as an Alternative}

The sort of flexible formula which Justice Marshall supports as an alternative to the two-tiered standard currently articulated by the Court in the equal protection field could be effectively employed as the Court's sole vehicle for protecting substantive rights and interests not given specific protection in the Constitution. Under such an approach, (a) the fundamental rights branch of the two-tiered equal protection standard would be dismantled; (b) statutes affecting rights specifically recognized in the Constitution would be evaluated under the constitutional provision in which the right is guaranteed rather than under equal protection standards; and (c) discriminatory legislation affecting interests not presently accorded protection under some other constitutional provision could be evaluated under the equal protection guarantee through a balancing of competing societal and individual interests. ${ }^{11}$ Such an approach would, at minimum, alleviate the present doctrinal confusion. More significantly, it would relieve the Court of pressure to designate certain interests as "rights," assign those "rights" a constitutional status, and then attempt to explain why certain interests are

110. Id. at 319 n.1.

111. As a logical corollary to this approach, the suspect categories branch of the compelling interest doctrine should perhaps be limited to the sort of racial classifications against which the equal protection clause was historically directed. The validity of other classifications could be determined on a case-by-case basis through the application of a balancing process. After all, when a court labels a classification "suspect" it is simply stating a conclusion that it is highly unlikely that such a classification could serve any legitimate and substantial governmental interest. The opinions in at least one recent case evidence an awareness of this deficiency in equal protection jurisprudence. See Craig v. Boren, 97 S. Ct. 451, 463-64 (Powell, J., concurring), id. at 464-66 (Stevens, J., concurring).

It should be noted that a number of recent studies have advocated adoption of a flexible equal protection standard as a supplement to existing doctrine in certain types of cases. See, e.g., Coven \& Fersh, supra note 14; Craven, Personhood: The Right to Be Let Alone, 1976 DUKE L.J. 699. 
within the scope of the Constitution and others are not, and why certain "rights" within the document's "implied" scope enjoy a more privileged status-irrespective of the circumstances in which they are asserted-than others which the Constitution is also said to protect.

In a sense, a flexible equal protection standard would not possess the clarity of the two-tiered approach in which the critical question is simply whether a regulation will be subjected to strict scrutiny-and almost certainly be struck down - or merely to the requirements of rationality — and almost certainly be upheld. As cases were decided, however, the mode of analysis employed by the Court in weighing the competing interests at issue would probably become increasingly well-defined. Moreover, while under such an approach the Court could never entirely escape the charge that it was acting as a super-legislature ruling on the wisdom of challenged legislation, it would at least not be arrogating to itself the authority to graft new rights onto the Constitution-rights which would be controlling and perhaps extended in reach in future cases and which, if labeled "fundamental," might be insulated from all governmental interference.

A flexible conception of substantive due proocess could serve essentially the same purpose as a flexible equal protection standard, of course, and reliance on due process would enable the Court to avoid the difficulties sometimes encountered in attempting to place certain categories of cases into an equal protection mold. There are a number of reasons, however, why resort to a flexible due process standard would be unsatisfactory-why, in fact, the doctrine of substantive due process should be discarded entirely.

In the first place, the force of precedent is clearly against its use. The Court appears to have abandoned substantive due process entirely in economic cases, except perhaps in the most abstract sense. ${ }^{12}$ Indeed, the anti-substantive due process tone of Justice Black's opinion for the Court in one such modern case, Ferguson v. Skrupa, ${ }^{113}$ was so strong that Justice Harlan felt compelled to append a brief statement implying that he, at least, would still require that economic regulations have some "rational relation to a constitutionally permissible objective." 114 Justice Stewart was probably correct when he asserted in a brief concurrence filed in Roe $v$. Wade ${ }^{115}$ that

112. Indicative of the Court's current attitude toward economic due process is North Dakota State Bd. of Pharmacy v. Snyder's Drug Stores, Inc., 414 U.S. 156, 164-67 (1973), upholding a state statute requiring that drug stores be owned or controlled by practicing pharmacists. See also Ferguson v. Skrupa, 372 U.S. 726 (1963); Olsen v. Nebraska ex rel. Western Reference \& Bond Ass'n, Inc., 313 U.S. 236 (1941); United States v. Carolene Prod. Co., 304 U.S. 144 (1938); West Coast Hotel Co. v. Parrish, 300 U.S. 379 (1937). See generally McCloskey, Economic Due Process and the Supreme Court: An Exhumation and Reburial, 1962 SuP. CT. REv. 34, 36-40.

113372 U.S. 726 (1963).

114. Id. at 733 (Harlan, J., concurring).

115. 410 U.S. 113 (1973) (Stewart, J., concurring). 
the modern Court, Skrupa to the contrary, had never abandoned substantive due process completely. ${ }^{116}$ But he was extremely hard-pressed to cite examples of modern cases bearing on the notion that "the 'liberty' protected by the due process clause of the Fourteenth Amendment covers more than those freedoms explicitly named in the Bill of Rights." 117 Of the cases he cited in support of the survival of nonprocedural due process, three pre-dated the 1937 revolution in the Court's conception of substantive due process; ${ }^{118}$ two recognized a right to international travel, ${ }^{119}$ but both of these cases could be conceptualized constitutionally as first amendment cases, and the decision in one of them ${ }^{120}$ rested on statutory grounds; two others involved a right of interstate travel not grounded in the due process guarantee; ${ }^{121}$ one was a voting case which employed the rhetoric of the fundamental rights branch of modern equal protection analysis; ${ }^{122}$ one involved racial discrimination and the equal protection element in the fifth amendment's due process clause; ${ }^{123}$ and another ${ }^{124}$ might be viewed as a free association case. ${ }^{125}$

Moreover, even though a form of substantive due process apparently did survive the 1937 revolution, the standard applied in economic cases is the extremely lenient one of rationality. And it seemed clear, until the 1973 abortion decisions ${ }^{126}$ at least, that the same lenient scrutiny would be given regulations affecting non-economic freedom. In a concurring opinion registered in Shapiro v. Thompson, ${ }^{127}$ for example, Justice Stewart contrasted the constitutional status of the right of interstate travel at issue there with the right of international travel recognized in Kent v. Dulles ${ }^{128}$ and Aptheker v. Secretary of State. ${ }^{129}$ The right to interstate travel, he asserted, was a fundamental right of citizenship which could be regulated only on a showing of compelling governmental interest. As such, it was to be distinguished from the right to foreign travel, which Justice Stewart implicitly characterized as "a mere conditional liberty subject to regulation and control under conventional [read lenient] due process or equal protection standards."130

116. Id. at $167-68$.

117. Id. at 168 .

118. Pierce v. Society of Sisters, 268 U.S. 510 (1925); Meyer v. Nebraska, 262 U.S. 390 (1923); Truax v. Raich, 239 U.S. 33 (1915).

119. Aptheker v. Secretary of State, 378 U.S. 500 (1964); Kent v. Dulles, 357 U.S. 116 (1958).

120. See Kent v. Dulles, 357 U.S. 116,125 (1958).

121. Shapiro v. Thompson, 394 U.S. 618 (1969); United States v. Guest, 383 U.S. 745 (1966).

122. Carrington v. Rash, 380 U.S. 89 (1965).

123. Bolling v. Sharpe, 347 U.S. 497 (1954).

124. Schware v. Board of Bar Examiners, 353 U.S. 232 (1957).

125. Cf. id. at $247-48$.

126. Roe v. Wade, 410 U.S. 113 (1973); Doe v. Bolton, 410 U.S. 179 (1973).

127. 394 U.S. 618, 642 (1969) (Stewart, J., concurring).

128. 357 U.S. $116(1958)$.

129. 378 U.S. 500 (1964).

130. 394 U.S. at 643 n.1. 
The present Court is apparently pursuing a rigid, two-tiered approach to substantive due process in which certain activities are characterized as fundamental rights and their regulation subjected to strict scrutiny while others (e.g., the freedom of personal appearance "assumed" to exist in Kelley v. Johnson $)^{131}$ are accorded meager status. This approach, too, would appear to have little support in precedent. It is true that modern fourteenth amendment "incorporation" cases ${ }^{132}$ and those defining the scope of due process as embodying a general requirement of "fair" proceedings ${ }^{133}$ have employed fundamental rights rhetoric. And while the implication of such cases would appear to be that only fundamental rights are to be given any degree of due process protection, there is some semblance of precedential support for the present Court's dual substantive due process approach in the combination of the rhetoric of these cases and that of early economic cases giving a special emphasis to "liberty of contract" 134 with the rhetoric of modern cases subjecting economic regulations to lenient scrutiny under substantive due process. Even so, the process is a strained one. Moreover, a rigid, two-tiered approach to substantive due process suffers from the same problems which Justice Marshall has seen in the application of such a formula in equal protection litigation.

Avoidance of doctrinal overload is another reason for rejecting further reliance on substantive due process. In the incorporation cases, the fourteenth amendment due process clause has served as a sort of constitutional shorthand for most Bill of Rights guarantees-even though the Bill of Rights itself includes a virtually identical clause, and the language of the due process clause seems ill-suited for this function in light of the generally accepted notion of modern cases that incorporated rights will have the same status under the fourteenth amendment that they enjoy under the first eight. ${ }^{135}$ Due process is also a general guarantee of "fundamentally fair"

131. 425 U.S. 238, 244 (1976).

132. The "incorporation" doctrine posits that certain of the limitations on federal power embodied in the Bill of Rights are incorporated in, and made applicable to the states by, the due process clause of the fourteenth amendment. Notable incorporation cases include Benton v. Maryland, 395 U.S. 784 (1969) (states subject to prohibition on former jeopardy); Duncan v. Louisiana, 391 U.S. 145 (1968) (states subject to sixth amendment jury trial provisions); Washington v. Texas, 388 U.S. 14 (1967) (right of accused to compulsory process for securing witnesses in his defense); Klopfer v. North Carolina, 386 U.S. 213 (1967) (speedy trial provisions); Pointer v. Texas, 380 U.S. 400 (1965) (defendant's right to cross-examine witnesses); Malloy v. Hogan, 378 U.S. 1 (1964) (privilege against self-incrimination); Gideon v. Wainwright, 372 U.S. 335 (1963) (right to assistance of counsel). See generally Palko v. Connecticut, 302 U.S. 319, 323-28 (1937).

133. See, e.g., In re Winship, 397 U.S. 358 (1970) (due process requires proof beyond reasonable doubt in juvenile action analogous to adult criminal proceeding).

134. E.g. , Adkins v. Children's Hospital, 261 U.S. 525, 545 (1923); Lochner v. New York, 198 U.S. 45, 53 (1905).

135. But see Apodaca v. Oregon, 406 U.S. 404 (1972); Johnson v. Louisiana, 406 U.S. 356 (1972) (upholding against sixth amendment, due process and equal protection claims Oregon and Louisiana laws which permitted criminal conviction by less-than-unanimous jury). 
proceedings in criminal cases, ${ }^{136}$ has been employed to require notice and some sort of hearing in certain civil cases, ${ }^{137}$ and was the vehicle for recent Court attacks on irrebuttable legal presumptions. ${ }^{138}$ The addition of substantive due process to the list of functions which the guarantee is used to perform arguably may be said unduly to clutter modern doctrinal lines in the due process field.

The Court has never assigned the equal protection clause the wide variety of functions given the due process guarantee, and adoption of a flexible equal protection formula obviously would not substantially increase-indeed, would probably help to reduce-the likelihood of doctrinal overload in the equal protection field. Adoption of such an approach would also require little if any modification of precedent. While substantive due process has been largely dormant in the Supreme Court for the past forty years, the equal protection guarantee- "the usual last restort of constitutional arguments" 139 in an earlier era-has flourished. Furthermore, there would appear to be as much precedential support for a flexible formula as there is for the rigid, two-tiered standard which the Burger Court now purports to embrace. Beginning with Skinner v. Oklahoma ${ }^{140}$ and Koremat$s u$ v. United States, ${ }^{141}$ modern equal protection cases have held that certain discriminatory regulations are to be accorded stricter scrutiny than others; it was not until the latter years of the Warren era, however, that the Court's opinions began to suggest that there was only one degree of strict scrutinythe rigorous, compelling interest standard. Moreover, even certain of the later Warren era opinions invoking the compelling interest test suggested that the degree of stricter-than-traditional scrutiny to be given a challenged regulation would vary with "the facts and circumstances behind the law, the interests which the State claims to be protecting, and the interests of those who are disadvantaged by the classification." 142

The Burger Court's purported rejection of a flexible formula and its restriction of the compelling interest test's fundamental rights branch to recognized rights grounded in some constitutional provision other than the equal protection guarantee render the test itself superfluous. Beyond this, the Court's position would appear to have little support in precedent. The

136. E.g., In re Winship, 397 U.S. 358 (1970).

137. E.g., Wolff v. McDonnell, 418 U.S. 539 (1974); Goldberg v. Kelly, 397 U.S. 254 (1970).

138. See Bell v. Burson, 402 U.S. 535 (1971).

139. Buck v. Bell, 274 U.S. 200, 208 (1927).

140. 316 U.S. 535 (1942) (Oklahoma statute providing for the sterilization of "habitual criminals").

141. 323 U.S. 214 (1944) (order promulgated by the Commanding General of the Western Defense command pursuant to an executive order, directing the exclusion of all persons of Japanese ancestry from a described West Coast Military Area).

142. Williams v. Rhodes, 393 U.S. 23, 30 (1968) (footnote omitted). See also Carrington v. Rash, 380 U.S. 89, 93 (1965). 
fundamental rights branch of equal protection analysis had its genesis in Justice Douglas' opinion for the Court in Skinner v. Oklahoma. ${ }^{143}$ When Justice Douglas spoke in Skinner of procreation as "one of the basic civil rights of man,"144 it is doubtful that he-or most of the members of the Court for which he spoke-was asserting that the Constitution guaranteed such a right apart from the equal protection context. After all, Skinner was decided during the period of the Court's intense frontal assault on prior Supreme Court judicial legislation in the economic field. Procreation can be viewed as a recognized constitutional guarantee only if one considers it implicit in the right of privacy, ${ }^{145}$ and the Court did not incorporate the privacy concept into the scope of recognized constitutional rights until decades after the Skinner decision. ${ }^{146}$ Likewise, certain other "fundamental rights" recognized by the Warren Court can be conceptualized as having some constitutional basis independent of equal protection only through resort to the convenient vacuity of the privacy concept. ${ }^{147}$ And certainly the right to vote in state elections, which the Warren Court recognized in a variety of equal protection contexts and characterized in a variety of ways ${ }_{148}$ could only have been bottomed in the equal protection guarantee. Finally, of course, strict scrutiny of state school segregation in Brown $v$. Board of Education ${ }^{149}$ and companion cases was triggered not by application of the concept of suspect categories, but by Chief Justice Warren's conclusion for the Court that an opportumity to an education, "where the state has undertaken to provide it, is a right which must be made available to all on equal terms" 150 - even though the Constitution clearly does not guarantee any right to an equal education. The restrictive reading which the Burger Court has given modern equal protection precedents in Rodriguez and related cases, then, is profoundly unconvincing.

Any precedential problems to which adoption of a flexible formula might give rise are further obviated by the Burger Court's own willingness to follow a flexible approach in certain cases, while simultaneously giving lip service to the rigid, two-tiered standard. At times, moreover, the Court

143. 316 U.S. 535 (1942).

144. Id. at 541 .

145. As did the Rodriguez majority, San Antonio Indep. School Dist. v. Rodriguez, 411 U.S. 1, 34 n.76 (1973).

146. This was accomplished in Griswold v. Connecticut, 381 U.S. 479 (1965).

147. See, e.g. , Levy v. Louisiana, 391 U.S. 68, 71 (1968) (the right to an "intimate, familial" relationship); Loving v. Virginia, 388 U.S. 1 (1967) (the right to marry).

148. See, e.g., Harper v. Virginia Bd. of Elections, 383 U.S. 663 (1966); Reynolds v. Sims, 377 U.S. 533 (1964).

150. Id. at 493. Chief Justice Warren's opinion in Bolling v. Sharpe, 347 U.S. 497 (1954), invalidating segregation in District of Columbia schools, did rely, of course, on suspect categories rhetoric. 
has appeared to embrace openly a flexible conception of equal protection. The Court's opinion in Bullock v. Carter ${ }^{151}$ invalidating Texas' scheme of exorbitant candidate filing fees, is perhaps most illustrative. Chief Justice Burger, a critic of the compelling interest test's inflexibility, ${ }^{152}$ spoke for the Bullock Court. Burger conceded that the Court had "not heretofore attached such fundamental status to candidacy as to invoke a rigorous standard of review." He added, however, that the rights of voters and candidates could not be neatly separated and that the Texas filing system had the effect of limiting voter choice by restricting candidate access to the ballot. The mere "existence of such barriers," he asserted, did "not of itself compel close scrutiny." Instead, it was. "essential to examine in a realistic light the extent and nature of their impact on voters." 153 Since the filing system had "a real and appreciable impact" and the impact was "related to the resources of the voters," close scrutiny was necessary. This meant, the Chief Justice concluded, that the regulations must be "found reasonably necessary to the accomplishment of legitimate state objectives." 154

Chief Justice Burger's line of reasoning in Bullock closely parallels the approach which Justice Marshall has advanced, particularly the reasoning of the latter's Rodriguez dissent. While leaving the precise standard of scrutiny somewhat obscure, the Chief Justice clearly articulated a standard of review for the Texas filing system which was both more rigorous than the traditional formula and less demanding than the requirements of the compelling interest doctrine. Indeed, all that would appear to remain is for the Court simply to acknowledge candidly its acceptance of a flexible approach, clarify its position, and follow it consistently in equal protection litigation.

\section{CONCLUSION}

There are those on and off the Supreme Court, of course, who will view the pliable nature of the flexible approach to equal protection as its principal weakness. Those of one persuasion will complain that adoption of a flexible formula may jeopardize interests (and classes) whose regulation is now subject to the virtually insurmountable requirements of the compelling interest test. Others will argue that the standard, like the substantive due process standard of early economic cases, leaves no limit but the sky to the interventionist tendencies of activist judges. The short answer to both

151. 405 U.S. 134 (1972).

152. See, e.g., Dunn v. Blumstein, 405 U.S. 330, 363-64 (1972) (Burger, C.J., dissenting), where the Chief Justice observed that to review governmental classifications under the compelling interest standard "is to condemn them all. So far as I am aware, no state law has ever satisfied this seemingly insurmountable standard, and I doubt one ever will, for it demands nothing less than perfection."

153. Bullock v. Carter, 405 U.S. 134, 142-43 (1972).

154. Id. at 144. 
groups is that the dangers they see in the Court's adoption of a flexible conception of equal protection will always be present on the Court, regardless of its doctrinal inclinations. As certain Burger Court decisions indicate, particular interests and classes can simply be removed from the categories now accorded strict scrutiny protection. ${ }^{155}$ By the same token, there would appear to be no limit to the number of interests which can be characterized as rights "implicit"' in the Constitution's scope.

In rejecting rigorous scrutiny of the discriminatory welfare regulations at issue in Dandridge $v$. Williams, ${ }^{156}$ Justice Stewart observed that strict review "of state economic or social regulation... would be far too reminiscent of an era when the Court thought the Fourteenth Amendment gave it power to strike down state laws 'because they may be unwise, improvident, or out of harmony with a particular school of thought." "157 With due respect, however, Justices on the modern Court, with the possibile exception of Justice Black, have always been willing-albeit with varying degrees of enthusiasm-to go beyond rights spelled out in the Constitution in reviewing challenged legislation. ${ }^{158}$ The members of the Burger Court are no exception, as the 1973 abortion decisions make perfectly clear.

Beyond a point-however wavering and uncertain that point may be-the legislative tendencies of Supreme Court Justices cannot be excused as the natural consequence of the Court's obligation to interpret a vaguely worded constitutional text. Rather, they are an affront to separation of powers and the concept of a written constitution. Even so, such tendencies would appear to be an inevitable ingredient of Supreme Court decisionmaking, whatever the Court's composition. The ultimate question, then, is not

155. Compare, for example, the Burger Court opinions in Mathews v. Lucas, 427 U.S. 495 (1976), and San Antonio Indep. School Dist. v. Rodriguez, 411 U.S. 1 (1973), with those of the Warren Court in Levy v. Louisiana, 391 U.S. 68 (1968), and Brown v. Board of Educ., 347 U.S. 483 (1954).

156. 397 U.S. 471 (1970).

157. Id. at 484 .

158. Justice Black opposed use of equal protection as "a handy instrument to strike down state laws which the Court feels are based on bad governmental policy," Harper v. Virginia Bd. of Elections, 383 U:S. 663, 673 (1966) (dissenting), and once said even of the lenient, rational basis standard of equal protection: "I regret to become involved at all in this formula useful only to invalidate state laws objectionable to the Court." Handwritten note on file in the Frank Murphy Papers, Michigan Historical Collection, University of Michigan. He also doubted whether the equal protection guarantee should ever have been given any semantic meaning or extended in reach beyond racial classifications. Interview with Hugo L. Black, Washington, D.C., July 6, 1971. In selected issue areas, however, he joined the Court's modern extensions of equal protection doctrine, and seemed to ascribe to the guarantee a more flexible meaning than he attached to other constitutional guarantees. Yarbrough, Justices Black and Douglas: The Judicial Function and the Scope of Constitutional Liberties, 1973 DukE L.J. 441, 472-83. Asked for his definition of an "invidious" discrimination, he would reply with a smile, "I don't know, no one knows," but would add that, in the final analysis, "we must make a judgment on the basis of [each] case." Interview with Hugo L. Black, supra. 
whether the Court should assume the role of "super-legislature," but how it should proceed in exercising that function. ${ }^{159}$ Under its articulated approach in both the equal protection and due process fields, the Court now effectively excludes certain interests from any protection and protects others from virtually all control, whatever the gravity of the state's interference with the interests at issue, whatever the weight of state justifications. Under a flexible approach, the Court could refuse to label certain activities "rights" and instead assign them an intermediate constitutional status. It could thus avoid locking itself further into the all-or-nothing scrutiny implicit in the two-tiered formula-a position from which it can extricate itself in specific instances only by obscuring the doctrinal basis of its decisions. Instead, the Court would examine on its own merits each challenged regulation and the interests asserted for and against its continued enforcement. Which of these courses the Court should pursue would appear obvious.

159. The debate over whether the Court should engage in "judicial legislation" still rages, of course. For recent treatments of the issue, see L. LUSKY, BY WHAT RIGHT? (1975); Ely, The Wages of Crying Wolf: A Comment on Roe v. Wade, 82 YALE L.J. 920 (1973); Grey, Do We Have an Unwritten Constitution?, 27 STAN. L. Rev. 703 (1975); Linde, Judges, Critics, and the Realist Tradition, 82 YALE L.J. 227 (1972). See also Tribe, The Supreme Court, 1972 TermForeword: Toward a Model of Roles in the Due Process of Life and Law, 87 HARV. L. REv. 1 (1973). For a defense (perhaps tongue-in-cheek) of the provocative notion that the fourteenth amendment's privileges and immunities guarantee could be activated as the basis for judicially created rights, see Kurland, The Privileges or Immunities Clause: 'Its Hour Come Round at Last'?, 1972 WASH. U.L.Q. 405. 